\title{
Erratum to: Features of soil redistribution and major element migration in a karst hillslope of Southwest China
}

\begin{abstract}
SONG Chang-shun',3 iDhttps://orcid.org/oooo-0oo3-2139-7265; e-mail: cssong20061211@163.com
\end{abstract}
JI Hong-bing1,2* iDhttps://orcid.org/oooo-0003-2438-7716; e-mail: ji.hongbing@hotmail.com

Howard Omar BECKFORD² (D https://orcid.org/oooo-ooo2-9296-3044; e-mail: howbecky@yahoo.com

CHU Hua-shuo ${ }^{1,3}$ iD https://orcid.org/oooo-ooo1-5289-5940; e-mail: chuhuashuo@yahoo.com

ZHANG Kun',3 i https://orcid.org/oooo-0oo2-5264-7434; e-mail: zhangkuno126@sina.cn

WANG Shi-jie1 (iD https://orcid.org/oooo-0002-6137-1871; e-mail: wangshijie@vip.skleg.cn

* Corresponding author

1 State Key Laboratory of Environmental Geochemistry, Institute of Geochemistry, Chinese Academy of Sciences, Guiyang 550002, China

2 School of Energy and Environmental Engineering, University of Science and Technology Beijing, Beijing 10oo83, China

3 University of Chinese Academy of Sciences, Beijing 10oo49, China

Citation: Song CS, Ji HB, Beckford HO, et al. (2018) Erratum to: Features of soil redistribution and major element migration in a karst hillslope of Southwest China. Journal of Mountain Science 16(2). https://doi.org/10.1007/s11629-0184921-6

(C) Science Press, Institute of Mountain Hazards and Environment, CAS and Springer-Verlag GmbH Germany, part of Springer Nature 2019

Erratum to: J. Mt. Sci. (2018) 15(9): 1892-1908

https://doi.org/10.1007/s11629-017-4791-3

The 3rd affiliation (Graduate University of the Chinese Academy of Sciences, Beijing 100049, China) is incorrect in the original article. It should be corrected into: University of Chinese Academy of Sciences, Beijing 100049, China.

The online version of the original article can be found at https://doi.org/10.1007/s11629-017-4791-3. 